\title{
Breeding for Climate Resilient Parthenocarpic Vegetables
}

\author{
P. Gangadhara Rao ${ }^{1}$ *, B.V.G. Prasad ${ }^{1}$, T. Kranthi Kumar ${ }^{2}$, T. Lakshmi \\ Tirupathamma $^{1}$, P. Roshni ${ }^{1}$ and T. Tejaswini ${ }^{1}$
}

${ }^{1}$ Department of Vegetable Science, ${ }^{2}$ Department of Fruit Science

Dr. YSR Horticultural University, India

*Corresponding author

\section{A B S T R A C T}

\section{Keywords}

Chromosomal

Changes, Genome

Editing Tools,

Growth Regulators,

Parthenocarpy,

Vegetables

Article Info

Accepted:

18 October 2018

Available Online:

10 November 2018
The development of fruits without fertilization is known as parthenocarpy. Parthenocarpy improves the fruit quality, processing attributes, production and productivity of vegetable crops like tomato, cucumber, watermelon etc. Absence of seeds can enhances the shelf life of the fruits, allowing a better conservation, fruit set in adverse climatic conditions, early and offseason production of vegetable crops. Therefore, it is important to ensure yield stability regardless of environmental conditions. Breeding of new cultivars with the ability to develop fruits without pollination or any artificial stimuli is a promising approach. Parthenocarpic vegetables can be natural or can be induced artificially by various methods like, use of plant growth regulators, distant hybridization, mutation, use of irradiated pollen, alternation in chromosome number, gene silencing, gene modifications and genome editing tools. Therefore, present review is focused on genetics, nature of gene action, mapping of QTLs and various breeding methods to induce parthenocarpy in vegetable crops.

\section{Introduction}

The development of fruits without fertilization is known as parthenocarpy. A plant is known to be parthenocarpic plant when its fruits are completely devoid of seeds or contain a very minute number of seeds or present aborted seeds. Consumers appreciate the seedless fruits by both in fresh consumption (e.g., water melon, grape, citrus and banana) as well as in processed fruits (e.g., frozen eggplant, tomato sauce) (Pandolfini, 2009). Seedless fruits can be obtained through parthenocarpy and by stenospermocarpy (seeds abort after fertilization) (Voraquaux et al., 2000). Pollen production activity is very sensitive to temperature in most of the vegetable crops including tomato. It requires a narrow range of temperature for pollination (i.e. $30^{\circ} \mathrm{C}-$ $35^{\circ} \mathrm{C} / 15^{\circ} \mathrm{C}-21^{\circ} \mathrm{C}$ (day/night). Severianin is a parthenocarpic cultivar of tomato which produces a higher yield and fruit set in colder temperatures (night temperature, $12^{\circ} \mathrm{C}$ ) than seeded cultivars (Hassan et al., 1987). In bell pepper, there is a blossom drop, if day temperature is $33^{\circ} \mathrm{C}$ or above or night temperature remain above $26.5^{\circ} \mathrm{C}$ or drop below $10^{\circ} \mathrm{C}$. Brinjal require long and worm 
temperature $\left(17-25^{\circ} \mathrm{C}\right)$ for better growth and yield. If temperature falls below $17^{\circ} \mathrm{C}$ vegetative growth is arrested and pollen deformity at bud stage occurs. High temperature stress $\left(35 / 20^{\circ} \mathrm{C}\right.$ day/night) during anthesis in common bean reduces pollen germination, pollen tube growth, fertilization, pod and seed set.

In cucurbits viz.,cucumber, gherkin, pumpkin, summer squash, musk melon, water melon and bitter gourd pollination and fruit set take place at optimum temperature range of $13-18^{\circ} \mathrm{C}$. On the other hand, fruit set in bottle gourd and ridge gourd takes place relatively at higher temperature (above $25^{\circ} \mathrm{C}$ ). Therefore, parthenocarpy could be potentially utilised for production of several vegetable crops in winter months (Tomes, 1997) or more generally, to ensure yield stability in case of unfavourable pollination conditions.

Moreover, it has been observed that seed development in fruits restricts the marketable yield in cucumber (Tiedjens, 1928; Denna, 1973) and tomato (Falavigna and Soressi, 1987). In the case of brinjal, the absence of seeds avoids browning and texture reduction of the pulp (Maestrelli et al., 2003). Some of the desirable quality parameters of parthenocarpic vegetables compare to seeded vegetables mentioned in Table 1. Furthermore, seeds can produce substances that accelerate the deterioration of the fruit (watermelon and eggplant). In this regard, the absence of seeds can enhances the shelf life of the fruits, allowing a better conservation. Parthenocarpy can be exploited for increasing winter and early production of horticultural crops (Ficcadenti et al., 1999 and Acciarri et al., 2002); there by increases the availability of horticultural products round the year.In addition, low temperatures during winter and early spring decreases the amount of fertile pollen. These factors reduce yields and fruit quality and delayed harvest due to lengthen the cultivation period. Green house cultivation of cucurbits (summer squash) not only allows offseason production but also protects from virus infestation.

The most important consideration during greenhouse cultivation is selection of variety and it should have ability to set fruits parthenocarpically. Much variation for parthenocarpic tendency has been observed in Cucurbita pepo (zucchini) germplasm (Martinez et al., 2014). Therefore, it is important to maintain fruit production regardless of environmental conditions. Breeding of new cultivars with the ability to develop fruits without pollination or any artificial stimuli is a promising approach (Yoshioka et al., 2018).

Rotino et al., (1999) suggested the ideotype of parthenocarpic trait, to improve the productivity of vegetable crops, has to satisfy the following three features: 1) production of marketable fruits without pollination, 2) percentage of fruit setting under adverse conditions is similar to that obtained under favourable growth conditions and 3) phenotypic expression of the trait should not display any negative effect on both intrinsic and extrinsic fruit quality. In addition to these three traits 4) multi-pistillate parthenocarpic (eg. cucumbers) is also most productive trait which has to be exploited at commercial level. C. pepo subsp. texana produce more than one female flower bud per leaf axil, introgression of this trait into cocozelle and zucchini germplasm and could result in increased yields (Paris, 2010).

\section{Advantages of parthenocarpic vegetable crops}

1. Stability in production and productivity-as pollination and fertilization were adversely affected by environmental stresses like low/high temperatures but parthenocarpic 
vegetables does not require pollination and fertilization to set fruits.

2. Consumer acceptance will increases parthenocarpic cucumber, seedless water melon and seedless pickled gherkin (Baker et al., 1973).

3. Novelty- seedless tomato, parthenocarpic cucumber and seedless water melon.

4. Improved quality and shelf life in brinjal as seeds are associated with bitter ness of fruit (Dalal et al., 2006).

5. Improved taste, high TSS - seedless tomato (Falavigna, et al., 1978; Lukyanenko, 1991).

6. Increase profitability for processing industries- seed less tomato (Lukyanenko, 1991)

7. Vertical fruit harvest- by growing of parthenocarpic cucumbers in green houses, continuous fruit set on vine will give more profits. This will cut down the cost and time to spend on pollen vibrators and manual pollination as these are necessary in green house grown vegetables.

8. No effect of "crown set inhibition" in parthenocarpic cucumbers so, fruits are continues.

9. Early yielder- parthenocarpic cucumbers.

10. Avoid the horizontal gene transfer, as major problem in transgenic approval (Varoquaux et al., 2000).

11. Protect genetically modified crops: linking a transgene with seedlessness would prevent unfair appropriation of the transgene by simply crossing the transgenic plant with another commercial variety (Varoquaux et al., 2000).

Majorly parthenocarpic vegetables can be broadly divided based on nature of their origin in to two types' i.e. natural parthenocarpy and artificial induction of parthenocarpy.

\section{Naturalparthenocarpy}

Naturally coccinia and some genotypes of cucumber produce seedless fruits.
Parthenocarpy is also regulated by environmental factors. Low temperature (freezing temperature $\leq 5^{\circ} \mathrm{C}$ )in bell pepper causes the parthenocarpic fruit development.Breeders started to use natural parthenocarpy at the end of the 1980's in brinjal (Prohens and Nuez, 2008). This trait is facultative as it is expressed only in cold conditions; as soon as the temperatures are favourable to pollination, normal fruit and seed set occurs. According to Fuzhong et al., (2005) the temperatures that induce parthenocarpy range from 7 to $10^{\circ} \mathrm{C}$ in brinjal. The elimination or cut of the stigmas of flowers bud is an easy way for getting the expression of parthenocarpy during a breeding process (Daunay, 1981/82; Fuzhong et al., 2005). Manik et al., (2000) investigated parthenocarpic fruiting behavior and fruit characteristics in different kakrol genotypes and concluded that only 'Rangpuri' genotype produced parthenocarpic fruits naturally with high number of flowers per plant, less vegetative growth, successive bearing of fruits and longer harvesting period.

\section{Artificial induction of parthenocarpy}

1. Use of plant growth regulators

2. Distant hybridization

3. Mutation

4. Use of irradiated pollen

5. Alternation in chromosome number

6. Gene silencing

7. Gene modifications

8. Genome editing tools

\section{Use of plant growth regulators}

The exogenous applications of plant growth hormones, like auxins, cytokinins and GAs, can influence many processes in plant growth and development. Application of these plant growth hormones may leads to development of parthenocarpic fruits in vegetable crops (Table 2). 


\section{Distant hybridization}

Intraspecific hybridization have been utilized for producing a facultative parthenocarpic line suitable for a hot and dry climate (normal fruit at moderate temperature) was first introduced in tomato (Hawthorn, 1937). Different facultative parthenocarpic tomato lines/cultivars developed through distant hybridization mentioned in Table 3. After that, various other parthenocarpic lines have been generated by using intraspecific hybridization e.g. Severenien, Oregon T5-4, Oregon Cherry, Oregon 11, Line 75/79, Line P-26, Line P-31, Line RG and IVT-line 2 in tomato (Baggett and Frazier, 1978; Philouze and Maisonneuve, 1978; Zijlstra, 1985) and 'AE-P' lines and 'Talina2/1' in eggplant (Kikuchi et al., 2008).Obligate parthenocarpy in aneuploid tomato developed from a cross between Solanum esculentum and $S$. peruvianum (Lesley and Lesley, 1941), IVT-line 1 was developed from a cross between $S$. habrochaites and S. lycopersicum (Zijlstra, 1985). Altered ploidy through interspecific hybridization is a common approach to obtain parthenocarpic fruits in various crops such as banana, watermelon and citrus (Fortescue and Turner, 2005). Afful et al., (2018) crossed three wild relatives of brinjal with seven cultivated accessions and the crosses, SA002$02 \times$ Solanum tovum and SMA003-03 $\times$ Solanum tovum devoid of seeds (parthenocarpic). This may be attributable to allelic incompatibility at fertilization (Behera and Singh, 2002). Singh (1978) reported the induction of parthenocarpy in Momordica dioica (spine gourd) and Tichosanthes dioca (pointed gourd) with pollen of related taxa ( $M$. charantia and Lagenaria leucantha) and the parthenocarpic fruit setting was higher with the pollen mixture of these two sps. (66\% against $36 \%$ in $M$. dioica), (85\% against 58\% in $T$. dioca) compared to natural pollination. Some cowpea lines developed from wild $x$ cultivated crosses have also been discovered to be parthenocarpic. Emasculated, unpollinated flowers on these lines do not abscise but produce seedless pods. Mature parthenocarpic pods are of normal size but contain only small shrivelled and poorly developed 'seed'. The 'seeds' within a single pod typically differ in size and apparent stage of development and are strongly attached to the pod. This suggests that partial development of some ovules occurs (Ehlers and Hall, 1997).

\section{Mutation}

Spontaneous mutations occur naturally and are used in classical breeding programmes. Good example of this is the parthenocarpic sha-pat mutants in the tomato line 'Montfavet 191' (Pecaut and Philouze, 1978). Various radiation treatments, such as helium accelerated ions in tomato (Masuda et al., 2004), soft-X-ray in watermelon (Sugiyama and Morishita, 2000; Kawamura et al., 2018) and gamma irradiation in Citrullus lanatus (Sugiyama and Morishita, 2001) have been used successfully to generate parthenocarpic mutants. Alkylating agents (EMS and EES) has been used to generate parthenocarpic mutants of Arabidopsis (fwf) and tomato (stock 2524: short anther mutant, sha) (Bianchi and Soressi, 1969; Soressi, 1970; Vivian-Smith et al., 2001).

\section{Use of irradiated pollen}

As parthenocarpy concern, the major advantage of using soft X-ray irradiated bottle gourd pollen is production of seedless watermelon (Citrullus lanatus) with diploid cultivars. When the pollen of bottle gourd was used to pollinate pistillate watermelon flowers, the rate of fruit set was $57.1 \%$ (with watermelon pollen $65.0 \%$ ). All parthenocarpic fruits produced by pollination with bottle gourd pollen were deformed (triangular or oblong shaped) however, fruit weight, rind 
thickness, flesh color and Brix in the parthenocarpic fruit were almost the same as control fruit. There were no normal seeds except for small, white empty seeds in the fruit obtained from pollinating with bottle gourd pollen. Bottle gourd pollen tubes did not reach the ovules of watermelon ovaries. Therefore, it was concluded that parthenocarpy resulting from pollination with bottle gourd pollen was stimulative parthenocarpy, not pseudo parthenocarpy (pseudogamy) (Sugiyama et al., 2014).

Another interesting study revealed the mechanism behind the production of seedless watermelon fruits after pollinating with soft X-ray (600 Gy) irradiated pollen of watermelon. The results indicated that, soft Xray irradiation did not damage the cell walls of the watermelon pollen and leading to normal pollination and fertilization. However, the chromosomal double helix of the watermelon pollen were damaged, thereby inhibiting embryotic developmental processes, leading to abortion of the embryo and degeneration of endosperm, which lead to the production of seedless watermelon (Qu et al., 2016).

\section{Alteration in chromosome number}

Unbalanced development of embryo and endosperm in triploid background has been utilized to yield parthenocarpic fruit. In watermelon seedless fruits with only residual integuments are obtained from $\mathrm{F}_{1}$ hybrid plants derived from cross between tetraploid and diploid parents (Kihara, 1951). Chromosome elimination in wide crosses may lead to the production of haploids, which are of enormous interest to the breeders. Haploid formation following interspecific hybridization is usually interpreted as parthenogenesis (Rowe 1974).Some of the parthenocarpic vegetables associated with various ploidy levels mentioned in Table 4.

\section{Gene silencing}

Parthenocarpy in cucumber may be promoted by a 'parallel switch,' namely, hormone dependent and hormone independent pathways. During hormone independent parthenocarpy, fruit set was promoted by hormone insensitive regulatory proteins, such as the NP-specialized proteins in 'EC1.' In the presence of sufficient hormones, young fruits formed through both hormone dependent and independent pathways could continuously grow to maturity. In the absence of hormones, the development of hormone sensitive fruits proceeds to fruit abortion, whereas the hormone insensitive fruits remain in a dormant state because of the increasing expression of abortion inhibiting proteins. However, the expansion of dormant fruits and their further promotion are unknown. Although the accurate regulation of parthenocarpy in cucumber remains unclear, Li et al., (2017) provide a theoretical framework for understanding the mechanism of parthenocarpy for its application in agricultural production

\section{Gene modifications}

Auxin, gibberellin and cytokinins or mixtures of these hormones have all been proven to be effective in inducing fruit development in the absence of fertilization in several crop species, for instance tomato and eggplants (Gillaspy et al., 1993).

The role of plant hormones in fruit set and genetic methods for obtaining seedless fruits by manipulating hormones action extensively reviewed by Pandolfini (2009). Martinez et al., (2014) observed the parthenocarpy of zucchini accessions is associated with down regulation of ethylene production in unpollinated fruits during the first days post anthesis (DPA) especially at 3 DPA. 
Biotechnology offers a wide range of opportunities and easier ways of obtaining parthenocarpic varieties than conventional breeding (Rotino et al., 1997 and Varoquaux et al., 2000). The processes of seed and fruit development which are intimately connected and synchronized, are controlled by phytohormones (Gillaspy et al., 1993). The regulatory region(s) of the gene represents the most important genetic information to control temporal and spatial expression of the gene of interest. These two parameters are relevant both to obtain parthenocarpy and to ensure an optimal expressivity of the parthenocarpic trait without affecting the vegetative plant growth. An excess or a defect in the expression of a phytohormone-synthetizing gene might cause the development of morphologically altered parthenocarpic fruits or an inefficient fruit set and growth, respectively (Falavigna and Rotino, 2006). Transgenic approach, gene silencing by RNA interference (RNAi) and by antisense RNA technology are powerful tools to interfere with the expression of genes. Rotino et al., (1997) reported that, transgenic tobacco and eggplants containing the DefH9iaaM transgene produce parthenocarpic fruits in the absence of pollination and that seeds are generated inside the fruit following pollination. Parthenocarpy has also been achieved in transgenic tomato plants carrying the DefH9-iaaM construct (Ficcadenti et al., 1999 and Pandolfini et al., 2002). The parthenocarpy produced by the introduction of the DefH9-iaaM construct is facultative. Carmi et al., (2003) also obtained parthenocarpy in tomato via specific expression of the rolB gene in the ovary. Here some of the examples are quoted for parthenocarpic fruit development by genetic modifications (Table 5).

\section{Genome editing tools}

Genome editing technologies include TALENs, ZFNs and CRISPR/Cas9. CRISPR/Cas9 system is the most popular among the genome editing technologies. The site-directed genome modification has been realized through development of sequencespecific nuclease based technologies that include Zinc Finger Nucleases (ZFNs) (Kim et al., 1996), Transcriptional Activator-Like Effector Nucleases (TALENs) (Bogdanove and Voytas, 2011) and most recently, Clustered Regulatory Interspaced Short Palindromic Repeat (CRISPR) Associated Protein System (CRISPR/Cas9) (Doudna and Charpentier, 2014). For rapid development of new parthenocarpic vegetable cultivars is possible only through CRISPR/Cas9 (Table $6)$.

\section{Genetics of parthenocarpy}

In several species, the mode of inheritance for parthenocarpic fruit set has been observed and it varies from a single gene to multiple quantitative trait loci (QTLs) (Table 7). In tomato (Lycopersicum esculentum L.) the following genes have been identified which are able to sustain the parthenocarpic traits: pat, pat-2, pat-3, pat-4 (Philouze 1983). However study lead to the conclusion that pat2 gene plays the major role and $m p$ gene, in the homozygous state, influences the phenotypic expression of pat-2 in both homozygous and heterozygous states (Vardy et al., 1989). In eggplant, a genetic tendency to parthenocarpy seems to be controlled by few genes with additive effect (Hennart, 1996). Cucumber is one of the plant species where parthenocarpic mutants have been more intensively used to breed cultivars for greenhouse cultivation. The parthenocarpic trait appears to be controlled by a single gene $\mathrm{Pa}$ ) expressing incomplete dominance and by modifier genes (Pike and Peterson, 1969). The segregation of $F_{2}$ population and test crosses for parthenocarpic fruit development suggested that parthenocarpy in gynoecious and parthenocarpic cucumber line is under the control of incomplete dominant gene (Jat et al., 2017). 
Table.1 Quality parameters of parthenocarpic vegetables compare to seeded one

\begin{tabular}{|c|c|c|}
\hline Crop & Parthenocarpic & Reference \\
\hline Watermelon & $\begin{array}{l}\text { The shape, flavour and yield are as good as seed-producing } \\
\text { cultivars and have a longer shelf life }\end{array}$ & Kihara, 1951 \\
\hline Watermelon & $\begin{array}{l}\text { No significant differences in sugar contents between seeded and } \\
\text { seedless watermelon }\end{array}$ & Kawamura et al.,2018 \\
\hline Cucumber & $\begin{array}{l}\text { Total sugar content of parthenocarpic fruits to be significantly } \\
\text { lower than that of the pollinated fruits, with significant negative } \\
\text { effects in the sweet taste of fruit }\end{array}$ & Li et al., 2014 \\
\hline Gherkin & $\begin{array}{l}\text { Seedless pickled gherkins are more crunchy, firmer and fleshier } \\
\text { than its seeded variety }\end{array}$ & $\mathrm{Bak}$ \\
\hline Tomato & $\begin{array}{l}\text { Seedless tomato fruits are tastier, more dry-matter (up to } 1 \% \text { ), } \\
\text { contain more sugars less acidity and less cellulose }\end{array}$ & Lukyanenko, 1991 \\
\hline Tomato & More soluble solids & Falavigna, et al., 1978 \\
\hline Tomato & $\begin{array}{l}\text { The fruit size, morphology and jelly fill in the locules of seedless } \\
\text { fruits were comparable with seeded fruits of the parental line }\end{array}$ & Carmi et al., 2003 \\
\hline Eggplant & High yield and fruit quality & Donzella et al., 2000 \\
\hline $\begin{array}{l}\text { Sweet } \\
\text { pepper }\end{array}$ & $\begin{array}{l}\text { Parthenocarpic fruit growth reduces yield fluctuation and blossom- } \\
\text { end rot (BER) }\end{array}$ & $\begin{array}{l}\text { Heuvelink and Körner, } \\
2001\end{array}$ \\
\hline
\end{tabular}

Table.2 Use of plant growth regulators for parthenocapic fruit development

\begin{tabular}{|c|c|c|c|c|}
\hline Crop & Growth regulator & $\begin{array}{l}\text { Stage of } \\
\text { treatment }\end{array}$ & Types of parthenocarpy & Reference \\
\hline Brinjal & $\begin{array}{l}\mathrm{GA}_{3} @ 2700 \text { ppm; 2-4- } \\
\mathrm{D} @ 2.5 \mathrm{ppm}\end{array}$ & $\begin{array}{l}\text { Foliar spray/cut } \\
\text { end styles at } \\
\text { freshly opened } \\
\text { flower stage }\end{array}$ & $\begin{array}{l}\mathrm{GA}_{3} \text { induced the completely } \\
\text { seedless fruits during all seasons. } \\
\text { 2,4-D, induced the development } \\
\text { of degenerated seeds }\end{array}$ & $\begin{array}{l}\text { Nothmann and } \\
\text { Koller, } 1975\end{array}$ \\
\hline Kokrol & $\begin{array}{l}\text { 2-4-D/2-4-5-T } \\
@ 100 \mathrm{mg} / \mathrm{L}\end{array}$ & $\begin{array}{l}\text { Pre-anthesis } \\
\text { sprays }\end{array}$ & Complete parthenocarpy & $\begin{array}{l}\text { Vijay and } \\
\text { Jalikop, } 1980\end{array}$ \\
\hline Kokrol & 2,4-D@50 ppm & $\begin{array}{l}\text { At the time of } \\
\text { anthesis }\end{array}$ & $90.0 \%$ parthenocarpy & $\begin{array}{l}\text { Chowdhury et } \\
\text { al., } 2007\end{array}$ \\
\hline Cucumber & GA@100mg/L & $\begin{array}{l}\text { Pre-anthesis } \\
\text { sprays }\end{array}$ & & $\begin{array}{l}\text { Choudhury and } \\
\text { Phatak, } 1958\end{array}$ \\
\hline $\begin{array}{l}\text { Pickling } \\
\text { cucumber }\end{array}$ & $\begin{array}{l}\text { Methylester chlorflurenol } \\
\text { (Morphactine) @ 100ppm }\end{array}$ & $\begin{array}{l}3 \text { weeks after } \\
\text { flowering }\end{array}$ & $\begin{array}{l}\text { Parthenocarpy (13 fruits per } \\
\text { plant and } 23 \mathrm{~g} \text { each fruit wt.) }\end{array}$ & $\begin{array}{l}\text { Wiebosch and } \\
\text { Berghoef, } 1974\end{array}$ \\
\hline Bottle gourd & CPPU@10-100 mg/L & $\begin{array}{l}2 \text { days before or } \\
\text { after anthesis }\end{array}$ & Complete parthenocarpy & Jing, 1999 \\
\hline $\begin{array}{l}\text { Water } \\
\text { melon }\end{array}$ & CPPU@0.5 mL/L & & parthenocarpy & $\begin{array}{l}\text { Kawamura et } \\
\text { al.,2018 }\end{array}$ \\
\hline Pumpkin & GA3@150ppm & & $96.9 \%$ seedless & $\begin{array}{l}\text { Sharif } \\
\text { Hossain, } 2015\end{array}$ \\
\hline Muskmelon & $\begin{array}{l}\text { CPPU@10mg/L and } \\
\text { BA }\end{array}$ & & & $\begin{array}{l}\text { Hayata et al., } \\
2000\end{array}$ \\
\hline
\end{tabular}


Table.3 Development of facultative parthenocarpy in tomato by distant hybridization

\begin{tabular}{|c|c|c|}
\hline $\begin{array}{l}\text { Parthenocarpic } \\
\text { line/cultivar }\end{array}$ & Cross involved & Reference \\
\hline Line RP75/79 & $\begin{array}{l}\text { Multiple cross Atom } \times \text { Bubjekosoko and } \\
\text { Heinemanns Jubilaum } \times \text { Priora (developed by } \\
\text { R. Reimann-Philipp) }\end{array}$ & Philouze and Maisonneuve 1978 \\
\hline Severianin & $\begin{array}{l}\text { L. esculentum and L. hirsutum (bred by N. } \\
\text { Soloviova) }\end{array}$ & $\begin{array}{l}\text { Philouze and Maisonneuve 1978; } \\
\text { Lin } \text { et al., } 1984\end{array}$ \\
\hline P-26, P-31, etc. & L. esculentum and L. pennellii & Stoeva et al., 1985 \\
\hline Line RG & L. esculentum and L. cheesmanii var. minor & Mikhailov and Georgiev 1987 \\
\hline IVT 1 & L esculentum and L. hirsutum & Zijlstra 1985 \\
\hline IVT 2 & L. esculentum and L. peruvianum & Zijlstra 1985 \\
\hline
\end{tabular}

Table.4 Parthenocarpic vegetables associated with various ploidy levels

\begin{tabular}{|c|c|c|c|c|}
\hline Vegetable & Species & Other changes & Ploidy no. & reference \\
\hline Tomato & $\begin{array}{l}\text { Solanaum esculentum } \\
(2 \mathrm{n}=2 \mathrm{x}=24)\end{array}$ & $\begin{array}{l}\text { Increase dry } \\
\text { matter, TSS }\end{array}$ & $\begin{array}{l}\text { Triploid } \\
(2 \mathrm{n}=3 \mathrm{x}=36)\end{array}$ & $\begin{array}{l}\text { Habashy et al., 2004; } \\
\text { Mackiewicz et al., } 1998\end{array}$ \\
\hline Tomato & $\begin{array}{l}\text { Solanaum esculentum } \\
(2 \mathrm{n}=2 \mathrm{x}=24)\end{array}$ & & Aneuploid & $\begin{array}{l}\text { Lesley and } \\
\text { Lesley } 1941\end{array}$ \\
\hline Cucumber & $\begin{array}{l}\text { Cucumis sativus } \\
(2 \mathrm{n}=2 \mathrm{x}=14) \\
(\text { Amphidiploid } \times \text { Diploid })\end{array}$ & & $\begin{array}{l}\text { Triploid } \\
(2 n=3 x=21)\end{array}$ & $\begin{array}{l}\text { Chen et al., 2003; } \\
\text { Habashy et al., 2004; } \\
\text { Mackiewicz et al., } 1998\end{array}$ \\
\hline Cucumber & $\begin{array}{l}c v . \text { "Butchers Disease } \\
\text { Resisting" (BDR) } \\
(2 \mathrm{n}=4 \mathrm{x}=28) 0.2 \% \\
\text { colchicine treatment }\end{array}$ & & $\begin{array}{l}\text { Autotetraploid } \\
(2 \mathrm{n}=4 \mathrm{x}=28)\end{array}$ & Grimbly, 1973 \\
\hline Watermelon & $\begin{array}{l}\text { Citrullus lanatus } \\
(2 \mathrm{n}=22) \text { (Autotetraploid } \times \\
\text { Diploid) }\end{array}$ & $\begin{array}{l}\text { High sugar } \\
\text { content, more } \\
\text { fruits per plant } \\
\text { and thin rind }\end{array}$ & $\begin{array}{l}\text { Triploid } \\
(2 n=3 x=33)\end{array}$ & Kihara, 1951 \\
\hline
\end{tabular}


Table.5 Seedless fruit production by gene silencing, transgenic and RNA interference approaches

\begin{tabular}{|c|c|c|c|c|}
\hline Gene & Function & Gene modification & Crop & Reference \\
\hline $\begin{array}{l}\text { DeH9- } \\
\text { iaaM }\end{array}$ & Auxin synthesis & $\begin{array}{l}\text { Ovule Specific } \\
\text { transgene expression }\end{array}$ & $\begin{array}{l}\text { Tobacco, eggplant, } \\
\text { tomato, raspberry, } \\
\text { cucumber. }\end{array}$ & $\begin{array}{l}\text { Rotino et al., 1997; } \\
\text { Pandolfini } \text { et al., 2002; Yin } \\
\text { et al., 2006; Mezzetti } \text { et al., } \\
2004\end{array}$ \\
\hline $\begin{array}{l}\text { SEP1/ } \\
\text { TM29 }\end{array}$ & Cytokinin & $\begin{array}{l}\text { Antisense or co- } \\
\text { suppression; MADS-box }\end{array}$ & Tomato & $\begin{array}{l}\text { Ampomah-Dwamena et al., } \\
\text { (2002) }\end{array}$ \\
\hline rolB & Auxin response & $\begin{array}{l}\text { Ovary/ Fruit Specific } \\
\text { transgene expression }\end{array}$ & Tomato & Carmi et al., 2003 \\
\hline SIIAA9 & Auxin signaling & $\begin{array}{l}\text { Antisense down } \\
\text { regulation }\end{array}$ & Tomato & Wang et al., 2005 \\
\hline AtARF8 & Auxin signaling & $\begin{array}{l}\text { Expression of Mutant } \\
\text { AtARF8-4 gene }\end{array}$ & Tomato & Goetz et al., 2007 \\
\hline SIDELLA & $\begin{array}{l}\text { Gibberellin } \\
\text { signaling }\end{array}$ & $\begin{array}{l}\text { Antisense down } \\
\text { regulation }\end{array}$ & Tomato & Marti et al., 2007 \\
\hline SlChs & $\begin{array}{l}\text { Flavonoid } \\
\text { biosynthesis }\end{array}$ & $\begin{array}{l}\text { RNAi-mediated } \\
\text { silencing }\end{array}$ & Tomato & Schijlen et al., 2007 \\
\hline SITPRI & $\begin{array}{l}\text { Ethylene } \\
\text { signaling }\end{array}$ & Over expression & Tomato & Lin et al., 2008 \\
\hline SIARF7 & Auxin signaling & $\begin{array}{l}\text { RNAi-mediated } \\
\text { silencing }\end{array}$ & Tomato & De Jong et al., 2009 \\
\hline AUCSIA & Auxin response & Gene silencing & Tomato & Molesini et al., (2009) \\
\hline PIN-4 & Auxin & RNAi & Tomato & Mounet et al., 2012 \\
\hline GA20OX & Gibberellic acid & Overexpression & Tomato & García-Hurtado et al., (2012) \\
\hline ARFs & Auxin response & RNA interference & Brinjal & Du et al., (2016) \\
\hline IAA & Auxin & $\begin{array}{l}\text { Differential expression } \\
\text { found in natural } \\
\text { parthenocarpic mutant }\end{array}$ & Brinjal & Chen et al., (2017) \\
\hline amiSlARF5 & Auxin signaling & m RNA down regulated & Tomato & Liu et al., 2018 \\
\hline
\end{tabular}

Table.6 Developing parthenocarpic tomato using CRISPAR/CAS-9

\begin{tabular}{|c|c|c|c|c|}
\hline Plant Species & Target genes & Editing tool & Phenotype & Reference \\
\hline Tomato & $\begin{array}{l}\text { AGL6, } \\
\text { AGAMOUS- } \\
\text { like }\end{array}$ & $\begin{array}{l}\text { CRISPR- } \\
\text { Cas9 }\end{array}$ & $\begin{array}{l}\text { Parthenocarpic phenotype. } \\
\text { Seedlless fruits with normal } \\
\text { weights and shapes under heat } \\
\text { stress conditions were set. }\end{array}$ & $\begin{array}{c}\text { Klap et al., } \\
2017\end{array}$ \\
\hline Tomato & $\begin{array}{l}\text { IAA9, auxin- } \\
\text { induced } 9\end{array}$ & $\begin{array}{l}\text { CRISPR- } \\
\text { Cas9 }\end{array}$ & $\begin{array}{c}\text { Enhancement of parthenocarpic } \\
\text { phenotype and change in leaf } \\
\text { shape. }\end{array}$ & $\begin{array}{l}\text { Ueta et al., } \\
\quad 2017\end{array}$ \\
\hline
\end{tabular}


Table.7 Genetic inheritance of parthenocarpy in vegetable crops

\begin{tabular}{|c|c|c|}
\hline Vegetable & Gene/ QTL & Reference \\
\hline Tomato & Several single-gene recessives & $\begin{array}{l}\text { Fos et al., 2001; Gorguet et } \\
\text { al., } 2005\end{array}$ \\
\hline Tomato (cv. Carobeta) & One recessive & $\begin{array}{l}\text { Georgiev and Mikhailov } \\
\text { (1985) }\end{array}$ \\
\hline Tomato (cv. IVTI) & One recessive & Zijlstra (1985) \\
\hline Tomato (cv. OregonT5-4) & $\begin{array}{l}\text { Two recessive genes, complementary } \\
\text { gene pairs }\end{array}$ & Kean and Baggett (1986) \\
\hline Tomato (cv. RP 75/59) & At least three recessive genes & Philouze (1989) \\
\hline Tomato (cv. MPK-1) & $\begin{array}{l}\text { Semi dominant gene (Pat-k) on } \\
\text { chromosome-1 }\end{array}$ & Takisawa et al., 2017 \\
\hline Tomato (cv. MPK-1) & $\begin{array}{l}\text { Only one major QTL, qpat1.1 for PL on } \\
\text { chromosome } 1\end{array}$ & Takisawa et al., 2018 \\
\hline $\begin{array}{l}\text { Pepino (Solanum } \\
\text { muricatum) }\end{array}$ & Single dominant gene & Prohens et al., 1998 \\
\hline Brinjal & single major gene & $\begin{array}{l}\text { Yoshida et al., 1998; Kuno } \\
\text { and Yabe, } 2005\end{array}$ \\
\hline Brinjal & Oligogenically and dominantly inherited & Daunay et al., (2001) \\
\hline Brinjal & $\begin{array}{l}\text { polygenic recessive and strongly } \\
\text { dependent on epistatic effects }\end{array}$ & Tian ShiBing et al., (2003) \\
\hline Brinjal & Two major-effect QTLs & Miyatake et al., 2012 \\
\hline Capsicum annum & Single recessive gene & Tiwari et al., 2011 \\
\hline Cucumber & $\begin{array}{l}\text { single incompletely dominant } \\
\text { gene } P c\end{array}$ & Pike and Peterson 1969 \\
\hline Cucumber & Single recessive gene & $\begin{array}{l}\text { Hawthorn and Wellington, } \\
\text { 1930; Meshcherov and } \\
\text { Juldasheva, } 1974\end{array}$ \\
\hline Cucumber & Many incompletely recessive genes & Kvasnikov et al., (1970) \\
\hline Cucumber & $\begin{array}{l}\text { Three independent major genes with } \\
\text { equal additive action }\end{array}$ & $\begin{array}{l}\text { de Ponti and Garretsen } \\
\text { (1976) }\end{array}$ \\
\hline Cucumber & $\begin{array}{l}\text { Quantitative trait controlled by two major } \\
\text { genes and polygenes }\end{array}$ & Yan et al., 2008 \& 2010 \\
\hline Cucumber & $\begin{array}{l}\text { Two major additive-dominant-epistatic } \\
\text { genes and additive-dominant polygene }\end{array}$ & Yan et al., 2010 \\
\hline Cucumber & $\begin{array}{l}\text { Seven QTLs with a major-effect QTL, } \\
\text { parth2-1 in chromosome } 2 .\end{array}$ & Wu et al., 2015 \\
\hline Cucumber & $\begin{array}{l}\text { A major-effect QTL Parth } 2.1 \text { and six } \\
\text { minor-effect QTLs }\end{array}$ & Wu et al., (2016) \\
\hline Processing cucumber & $\begin{array}{l}\text { Seven QTLs, parth7.1 early } \\
\text { parthenocarpic fruit set. }\end{array}$ & Lietzow et al., 2016 \\
\hline $\begin{array}{l}\text { Summer squash } \\
\text { (cv. Whitaker) }\end{array}$ & Single gene with incomplete dominance & de Menezes et al., 2005 \\
\hline Muskmelon & Recessive genes & Yoshioka et al., 2018 \\
\hline
\end{tabular}


Table.8 Molecular markers and mapping of parthenocarpy

\begin{tabular}{|c|c|c|c|c|}
\hline Crop & Gene/QTL & $\begin{array}{l}\text { Type, Number of } \\
\text { Markers and } \\
\text { Population }\end{array}$ & $\begin{array}{c}\text { Flanking Marker and } \\
\text { Distance and Chromosome } \\
\text { Number }\end{array}$ & Reference \\
\hline $\begin{array}{l}\text { Cucumbe } \\
\mathbf{r}\end{array}$ & $\begin{array}{l}\text { A major- } \\
\text { effect QTL } \\
\text { Parth2.1 } \\
\text { and six } \\
\text { minor- } \\
\text { QTLs }\end{array}$ & 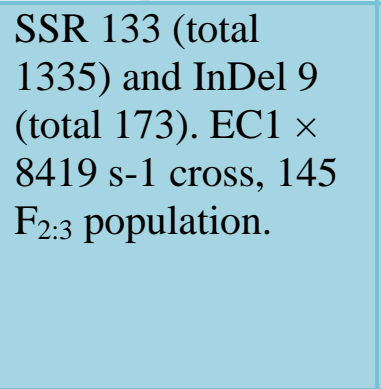 & $\begin{array}{l}\text { Seven novel QTLs were } \\
\text { identified on chromosomes } \\
1,2,3,5 \text { and } 7 . \\
\text { Parthenocarpy } 2.1 \text { (Parth } \\
\text { 2.1), a QTL on chromosome } \\
\text { 2, was a major-effect QTL } \\
\text { (flanking markers } \\
\text { SSR00684-SSR22083). }\end{array}$ & $\begin{array}{l}\text { Wu et al., } \\
\text { (2016) }\end{array}$ \\
\hline $\begin{array}{l}\text { Cucumbe } \\
\mathbf{r}\end{array}$ & & & $\begin{array}{l}\text { Ten QTLs associated with } \\
\text { parthenocarpy distributed } \\
\text { across four genomic regions } \\
\text { as well as eight linked AFLP } \\
\text { markers in cucumber. }\end{array}$ & $\begin{array}{l}\text { Sun et al., } \\
2006 b\end{array}$ \\
\hline Tomato & Pat & & $\begin{array}{l}\text { Localized on the long arm of } \\
\text { chromosome } 3 \text {. }\end{array}$ & $\begin{array}{l}\text { Beraldi } \text { et } \\
\text { al., } 2004\end{array}$ \\
\hline Tomato & $\begin{array}{l}\text { pat4.1, } \\
\text { pat9.1 and } \\
\text { pat5.1 }\end{array}$ & $\begin{array}{lr}\text { S. } & \text { habrochaites } \\
\text { LYC4, } & S . \\
\text { lycopersicum cv. } & \text { Moneymaker; Two } \\
\text { BC5S1 populations } \\
\text { (174 \& } 183 \text { plants), } \\
\text { CAPS and SCAR } \\
\text { markers }\end{array}$ & $\begin{array}{l}\text { F2 population (160 plants); } \\
\text { IVT-line } 1 \text {, S. lycopersicum } \\
\text { cv. Moneymaker. }\end{array}$ & $\begin{array}{l}\text { Gorguet } e t \\
\text { al., } 2008\end{array}$ \\
\hline Eggplant & & $\begin{array}{l}\text { F2 populations (135 } \\
\text { and 93) } \\
\text { derived from } \\
\text { intraspecific crosses } \\
\text { between two non- } \\
\text { parthenocarpic } \\
\text { lines (LS1934 and } \\
\text { Nakate-Shinkuro) } \\
\text { and a } \\
\text { parthenocarpic } \\
\text { line (AE-P03). (324 } \\
\text { SSR; 630 SNP) }\end{array}$ & $\begin{array}{l}\text { Two QTLs on } \\
\text { chromosomes } 3 \text { and } 8 \text {, which } \\
\text { we denoted as Controlling } \\
\text { parthenocarpy3.1 (Cop3.1) } \\
\text { and Cop8.1, respectively }\end{array}$ & $\begin{array}{l}\text { Miyatake } \\
\text { et al., } \\
2012\end{array}$ \\
\hline
\end{tabular}


Fig.1 Breeding programme applied to select the parthenocarpic pickling cucumber lines (De Ponti, 1976)

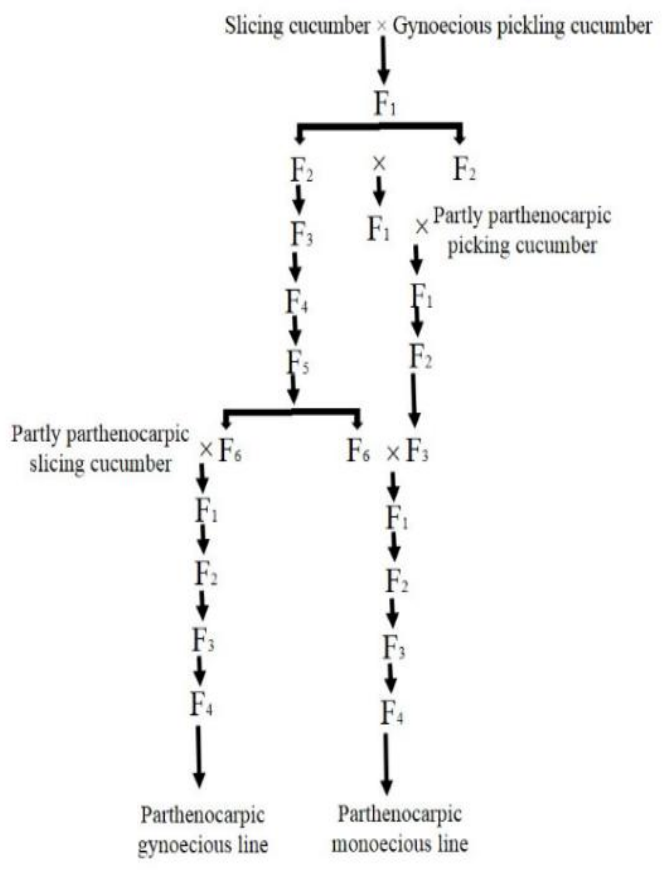

Fig.2 Development of parthenocarpic tropical gynoecious lines in cucumber (More and Budgujar, 2002)

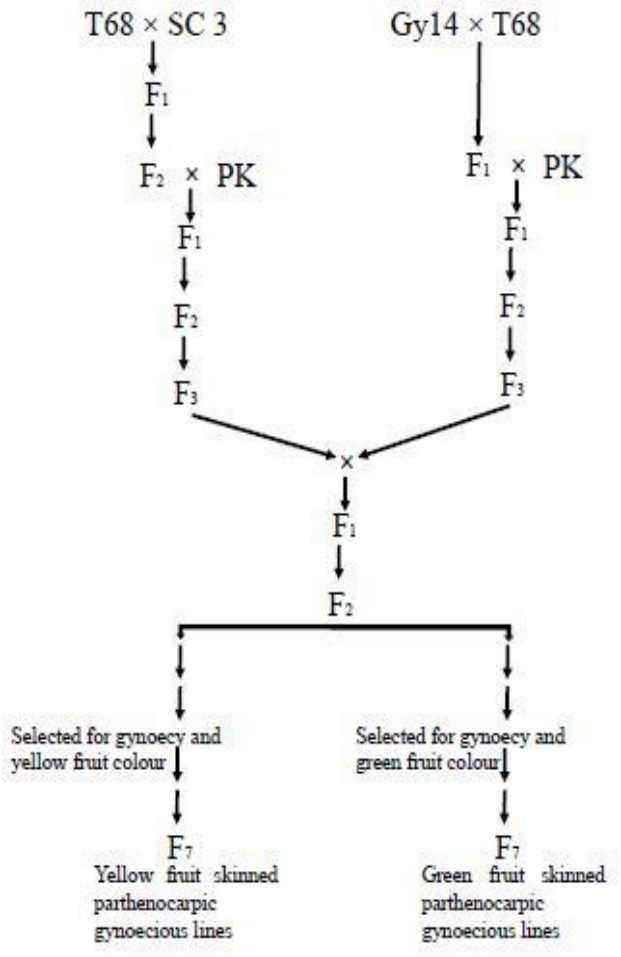


Molecular markers and mapping of parthenocarpy

The first attempt of mapping of parthenocarpy gene, pat, in tomato was done by Beraldi et al., (2004). Recently, four QTLs associated with parthenocarpy were identified and mapped in tomato (Gorguet et al., 2008). The isolation of these QTLs will enhance not only our understanding about fruit set in tomato but also open possibilities to develop seedless fruits in other economically important species solanaceous vegetable crops.Intraspecific linkage map in eggplant for parthenocarpy was developed (Barchi et al., 2010). Quantitative trait locus (QTL) analysis of eggplant by using co-dominant simple sequence repeat and single nucleotide polymorphism markers revealed that two QTLs on chromosomes 3 and 8, which are controlling parthenocarpy 3.1 (Cop3.1) and Cop8.1, respectively (Miyatake et al., 2012).Using these maps, attempts at mapbased cloning have been made, and parthenocarpy causing genes may soon be isolated.We mentioned the markers and QTLs of major parthenocarpic vegetables in Table 8.

\section{Breeding methods to develop parthenocarpic vegetables}

Parthenocarpy can have a genetic basis or it can be artificially induced. Genetic parthenocarpy is called obligatory when the expression of the parthenocarpy trait is not influenced by external factors and facultative if it occurs only under conditions adverse for pollination and fertilization. Artificially induced parthenocarpy can be observed in several plant species by treating flowers with plant growth factors or by pollination with incompatible pollen or X-rays irradiated pollen (Falavigna and Rotino, 2006). The parthenocarpic trait can be transferred to new types with a few backcrosses from a donor line (Sun et al., 2006a). Breeding of parthenocarpic vegetables and incorporation of additional desirable gene along with parthenocarpy through conventional breeding methods will take very long time and also tedious (Fig. 1 and 2). Using of advanced breeding methods like MAS will enhance the accuracy and rapid advancement of generation and genome editing tools likeCRISPR/Cas9 is very recent trending technique following for fast breeding of parthenocarpic vegetables.

\section{References}

Acciarri, N., Restaino., Vitelli, G., Perrone, D., Zottini, M., Pandolfini, T., Spena, A.,Rotino, G.L. 2002. Genetically modified parthenocarpic eggplants: improved fruit productivity under both greenhouse and open field cultivation. BMC Biotechnology. 2:1-7.

Afful, N.T., Nyadanu, D., Akromah, R., Amoatey H. M., Annor, C. and Diawouh, R. G. 2018. Evaluation of crossability studies between selected eggplant accessions with wild relatives $S$. torvum, $S$. anguivi and $S$. aethopicum (Shum group). Journal of Plant Breeding and Crop Science. 10 (1): 1-12.

Ampomah-Dwamena, C., Morris, B.A., Sutherland, P., Veit, B. and Yao, JL. 2002. Down-regulation of TM29, a tomato SEPALLATA homolog, causes parthenocarpic fruit development and floral reversion. Plant Physiology. 130:605-617.

Baggett, J.R. and Frazier, W.A. 1978. Oregon T5-4 Parthenocarpic Tomato Line. Hortscience. 13: 599-599.

Baker, L. R., Wilson, J. and E. Scott, J. W. 1973 Seedless pickles - a new concept. Farm Science.227: 1-12.

Barchi, L., Lanteri, S., Portis, E., Stagel, A., Vale, G., Toppino, L and Rotino, G L.2010 Segregation distortion and linkage analysis in eggplant (Solanum melongena L.). Genome. 53:805-15. 
Behera, T.K, Singh, N.2002. Inter-specific crosses between eggplants (Solanum melongena L.) with related Solanum species. Scientia Horticulture. 95:165172.

Beraldi, D., Picarella, M.E., Soressi, G.P., Mazzucato, A. 2004. Fine mapping of the Parthenocarpic fruit (pat) mutation in tomato. Theoretical and Applied Genetics. 108: 209-216.

Bianchi, A., Soressi, G.P. 1969. Mutanti di pomodoro artificialmente indotti suscettibili di utilizzazione nel miglioramento genetico. Sementi EletteXV. 3: 2-6.

Bogdanove, A.J. and Voytas, D.F.2011.TAL effectors: customizable proteins for DNA targeting. Science. 333:1843-1846.

Carmi, N., Salts, Y., Dedicova, B., Shabtai, S., Barg, R., 2003. Induction of parthenocarpy in tomato via specific expression of the rolB gene in the ovary. Planta. 217: 726-735.

Chen, J.F., Luo, X.D., Staub, J.E., Jahn, M.M., Qian, C.T., Zhuang, F.Y., Ren G. 2003. An allotriploid derived from a amphidiploid x diploid mating in Cucumis - I: Production, micropropagation and verification. Euphytica. 131: 235-241.

Chen, X., Zhang, M., Tan, J., Huang, S., Wang, C., Zhang, H., Tan, T. 2017. Comparative transcriptome analysis provides insights into molecular mechanisms for parthenocarpic fruit development in eggplant (Solanum melongena L.). PLoS One.12: e0179491.

Choudhury, B. and S. C. Phatak. 1958. Sex expression and fruit development in cucumber (Cucumis sativus L) as affected by gibberellin. Indian Journal of Horticulture. 16: 233-235.

Chowdhury, R.N., Rasul, M.G., Islam, A.A., Mian, M.A.K. and Ahmed, J.U. 2007. Effect of plant growth regulators for induction of parthenocarpic fruit in kakrol (Momordica dioica Roxb.). Bangladesh Journal of Plant Breeding and Genetics. 20(2): 17-22.

Dalal, M., Dani, R.G. and Kumar, P.A. 2006.
Current trends in the genetic engineering of vegetable crops. Scientia Horticulturae. 107(3):215-225.

Daunay, M.C. 1981. L'Aubergine. In Rapport d'activité de la station d'Amélioration des plantes maraîchères, Avignon-Montfavet, France.19-23.

Daunay, M.C., Lester, R.N., Gebhardt, C., Hennart, J.W., Jahn, M., Frary, A., and Doganlar, S. 2001. Genetic resources of eggplant (Solanum melongena L.) and allied species: a new challenge for molecular geneticists and eggplant breeders. P. 251-274. In: R.G. van den Berg, G.W.M. Barendse, G.M. van der Weerden and C. Mariani (eds.), Solanaceae V, Advances in Taxonomy and Utilization, Nijmegen University Press, Nijmegen, the Netherlands.

De Jong, M., Wolters-Arts, M., Feron, R., Mariani, C., Vriezen, W.H. 2009.TheSolanum lycopersicum auxin response factor 7 (SlARF7) regulates auxin signaling during tomato fruit set and development. Plant journal.5:160-170.

De Menezes, C.B., Maluf, W.R., de Azevedo, S.M., Faria, M.V., Nascimento, I.R., Nogueira, D.W., Gomes, L.A.A., Bearzoti, E. 2005. Inheritance of parthenocarpy in summer squash (Cucurbita pepo L.). Genetics and molecular biology research.4:39-46.

De Ponti, O.M.B. 1976. Breeding parthenocarpic pickling cucumbers (Cucumis sativus L.): Necessity, genetical possibilities, environmental influences and selection criteria. Euphytica. 25: 29.

De Ponti., O. M. B. and Garretsen, F.1976. Inheritance of parthenocarpy in pickling cucumbers (Cucumis sativus L.) and linkage with other characters. Euphytica. 25(1): 633-642.

Denna, D.W. 1973. Effect of genetic parthenocarpy and gynoecious flowering habit on fruit production and growth of cucumber, Cucumis sativus L. Journal of American society of Horticultural Sciences. 98:602-604.

Donzella, G., Spena, A., Rotino, G.L. 2000. 
Transgenic parthenocarpic eggplants, superior germplasm for increased winter production. Molecular breeding. 6, 79-86.

Doudna, J.A. and Charpentier, E. 2014. Genome editing. The new frontier of genome engineering with CRISPR-Cas9. Science. 346:1- 9.

Du, L., Bao, C., Hu, T., Zhu, Q., Hu, H., He, Q. and Mao, W., 2016. SmARF8, a transcription factor involved in parthenocarpy in eggplant. Molecular genetics and genomics. 291(1): 93-105.

Ehlers, J.D. and Hall, A.E. 1997. Cowpea (Vigna unguiculata L. Walp.). Field Crops Research. 53: 187-204.

Falavigna, A. and Soressi, G.P. 1987. Influence of the pat-sha gene on plant and fruit traits in tomato (L. esculentum Mill.). In Modern Trends in Tomato Genetics and Breeding, p. 128, Proceedings of the $10^{\text {th }}$ Meeting of the EUCARPIA Tomato Working Group.

Falavigna, A., Badino, M. and Soressi, G. P. 1978. Potential of the monomendelian factor pat in the tomato breeding for industry. Genetica Agraria. 32:159-160.

Falavigna., A. and Rotino, G. L. 2006. Parthenocarpy, a Strategy for FruitDevelopment underAdverse Environmental Conditions.Seminar Nasional Pemanfaatan Bioteknologi untuk Mengatasi Cekaman Abiotik pada Tanaman.42-51.

Ficcadenti, N., Sestili, S., Pandolfini, T., Cirillo, C., Rotino, G.L., Spena, A. 1999.Genetic engineering of parthenocarpic fruit development in tomato. Molecular Breeding. 5: 463-470.

Fortescue, J.A and Turner, D.W.2005. The anatomy of ovule ontogeny of banana, plantain and enset (Musaceae). Scientia Horticulturae. 104: 479-492.

Fos, M., Proano, K., Nuez, F and GarciaMartinez, J. L.2001.Role of gibberellins in parthenocarpic fruit development induced by the genetic system pat-3/pat-4 in tomato. Physiol Plant.111:545-50.

FuZhong, L., Lian Yong and Chen YuHui. 2005. Study on characteristics of parthenocarpic germplasm of eggplant. IPGRI Newsletter for Asia, the Pacific and Oceania. 45: 21-22.

García-Hurtado N., Carrera, E., Ruiz-Rivero, O., López-Gresa, M.P., Hedden, P., Gong, F., García-Martínez, J.L. 2012. The characterization of transgenic tomato overexpressing gibberellin 20-oxidase reveals induction of parthenocarpic fruit growth, higher yield, and alteration of the gibberellin biosynthetic pathway. Journal of Experimental Botany. 63:5803-5813.

Georgiev, K. and Mikhailov L.1985. Variety Caro beta-a new source of parthenocarpy in tomato. Genetic Selection in Bulgaria. 18:264-266.

Gillaspy, G., Ben-David, H. and Gruissem, W. 1993. Fruits: a developmental perspective. Plant Cell. 5: 1439-1451.

Goetz, M., Hooper, L.C., Johnson, S.D., Rodrigues, J.C., Vivian-Smith, A., Koltunow, A.M. 2007. Expression of aberrant forms of AUXIN RESPONSE FACTOR8 stimulates parthenocarpy in Arabidopsis and tomato. Plant Physiol. 145: 351-366.

Gorguet, B., Eggink, P.M., Ocana, J., Tiwari, A., Schipper, D., Finkers, R., Visser RGF., Van Heusden, A.W. 2008. Mapping and characterization of novel parthenocarpy QTLs in tomato. Theoretical and Applied Genetics 116: 755-767.

Gorguet, B., Van Heusden, A.W. and Lindhout, P. 2005. Parthenocarpic fruit development in tomato. Plant Biollogy.7:131-39.

Grimbly, P. E. 1973. Polyploidy in the glasshouse cucumber (Cucumis sativus L.). Euphytica. 22(3):479-483.

Habashy, A.A., Testa, G., Mosconi, P., Caccia, R., Mazzucato, A., Santange-Lo E., Soressi, G.P. 2004. Parthenocarpy restores fruitfulness in sterile triploid $(3 \mathrm{x})$ tomatoes artificially obtained by crossing $4 \mathrm{x} \times 2 \mathrm{x}$ somaclones. Journal of Horticultural Science \& Biotechnology.79: 322-328.

Hassan, A.A. 1987. Genetics and physiology of parthenocarpy in tomato. Acta 
Horticulture.200:173-183.

Hawthorn, L. R. and Wellington, R. 1930. Bulletin: Number 580: Geneva, a Greenhouse Cucumber that Develops Fruit without Pollination.

Hawthorn, L.R. 1937. Seedlessness in tomatoes. Science. 85: 199.

Hayata, Y., Niimi, Y., Inoue, K., Kondo, S. 2000. CPPU and BA, with and without pollination, affect set, growth and quality of muskmelon fruit. HortScience. 35:868870.

Hennart, J.W. 1996.Selection de l'aubergine. P.H.M. Rev. Horticole. 374:37-40.

Heuvelink, E. and Körner, O. 2001. Parthenocarpic fruit growth reduces yield fluctuation and blossom-end rot in sweet pepper. Annals of Botany. 88(1): 69-74.

Jat, G.S., Munshi, A.D., Behera, T.K. and Bhardwaj, C. 2017. Inheritance of parthenocarpy in gynoecious cucumber (Cucumis sativus L.) cultivar PPC-2. Journal of Horticultural Sciences. 12(2): 193-197.

Jing, Q.Y. 1999. Parthenocarpy induced by $N$ (2-chloro-4-pyridyl)-N\%-phenylurea (CPPU) prevents flower abortion in Chinese white-flowered gourd (Lagenaria leucantha). Environmental and Experimental Botany.42: 121-128.

Kawamura, S., Ida, K., Osawa, M., and Ikeda, T. 2018. No Effect of Seed Presence or Absence on Sugar Content and Water Status of Seeded and Seedless Watermelon Fruits. HortScience. 53(3): 304-312.

Kean, D. and Baggett, J.R. 1986. The inheritance of parthenocarpy in Oregon T5-4 tomato. Journal of American society of Horticulture science. 111:596-599.

Kihara, H. 1951.Triploid water melons. Proceedings of the American Society for Horticultural Science. 58: 217-230.

Kikuchi, K.H.I., Matsuo, S., Fukuda, $M$ and Saito, T. 2008. Stability of fruit set of newly selected parthenocarpic eggplant lines. Scientia Horticulturae. 115: 111116.

Kim,Y.G., Cha, J. and Chandrasegaran, S.
1996. Hybrid restriction enzymes: zinc finger fusions to Fok I cleavage domain. PNAS. USA, 93:1156-1160.

Klap, C., Yeshayahou, E., Bolger, A.M., Arazi, T., Gupta, S.K., Shabtai, S. 2017. Tomato facultative parthenocarpy results from SIAGAMOUS-LIKE 6 loss of function. Plant Biotechnology. 15: 634-647.

Kuno, S. and Yabe, K. 2005. Genetic analysis of parthenocarpy and spineless in the F2 segregating. Research Bulletin of Aichi Agricultural Research Center.37:29-33.

Kvasnikov, B.V., N.T. Rogova, S.I. Tarakonova, and Ignatova, I. 1970. Methods of breeding vegetable crops under the covered ground. Trudy-poPrikladnoi-Botanike-Genetiki-ISelektsii. 42: 45-57.

Lesley, M.M. and Lesley, J.W. 1941. Parthenocarpy in a tomato deficient for a part of a chromosome and its aneuploid progeny. Genetics. 26:374-386.

Li, J., Wu, Z., Cui, L., Zhang, T., Guo, Q., Xu, J., Jia, L., Lou, Q., Huang, S., Li, Z. and Chen, J. 2014.Transcriptome comparison of global distinctive features between pollination and parthenocarpic fruit set reveals transcriptional phytohormone cross-talk in cucumber (Cucumis sativus L).Plant Cell Physiology. 55: 1325-1342.

Li, J., Xu, J., Guo, Q.W., Wu, Z., Zhang, T., Zhang, K.J., Cheng, C.Y., Zhu, P.Y., Lou, Q.F. and Chen, J.F. 2017. Proteomic insight into fruit set of cucumber (Cucumis sativus L.) suggests the cues of hormone-independent

parthenocarpy. BMC genomics. 18(1): 896.

Lietzow, C.D., Huayu Zhu, Sudhakar Pandey, Michael J. Havey, Yiqun Weng. 2016. QTL mapping of parthenocarpic fruit set in North American processing cucumber. Theoretical and Applied Genetics.129:2387-2401.

Lin, S., George, W.L. and Splittstoesser, W.E. 1984. Expression and inheritance of parthenocarpy in "Severianin" tomato. Journal of Heredity.75:62-66.

Lin, Z.F., Arciga-Reyes, L., Zhong, S., 
Alexander, L., Hackett, R., Wilson, I. Grierson, D.2008.SITPR1, a tomato tetratricopeptide repeat protein, interacts with the ethylene receptors NR and LeETR1, modulating ethylene and auxin responses and development. Journal of Experimental Botany.59:4271-4287.

Liu, S., Zhang, Y., Feng, Q., Qin, L., Pan, C., Lamin-Samu, A. T. and Lu, G. 2018. Tomato auxin response factor 5 regulates fruit set and development via the mediation of auxin and gibberellin signaling. Scientific reports. 8(1): 2971.

Lukyanenko, A.N. 1991. Parthenocarpy in tomato. In Monographs on Theoretical and Applied Genetics: Genetics Improvement of Tomato (Kalloo, G., ed.). 167-178, Springer-Verlag.

Mackiewicz, H.O., Malepszy, S., Sarreb, D.A., Narkiewicz, M. 1998. Triploids in cucumber: II. Characterization of embryo rescue plants. Gartenbauwissenschaft.63: 125-129.

Maestrelli, A., Lo Scalzo, R., Rotino, G.L., Acciarri, N., Spena, A., Vitelli, G., Bertolo, G. 2003. Freezing effect on some quality parameters of transgenic parthenocarpic eggplants. Journal of food engineering. 56: 285-287.

Manik, M. N. I., Rasul, M. G., Rahman, M. M., Ozaki, Y and Okubo, H. 2000. Parthenocarpic fruiting behavior in kakrol (Momordica dioica Roxb.). Journal of the Faculty of Agriculture, Kyushu University. 45(2): 459-463.

Marti, C., Orzaez, D., Ellul, P., Moreno, V., Carbonell, J., Granell, A. 2007.Silencing of DELLA induces facultative parthenocarpy in tomato fruits. Plant Journal.52: 865-876.

Martínez, C., Manzano, S., Megías, Z., Garrido, D., Picó, B. and Jamilena, M. 2014. Sources of parthenocarpy for Zucchini breeding: relationship with ethylene production and sensitivity. Euphytica. 200(3):349-362.

Masuda, M., Agong, S.G., Tanaka, A., Shikazono, N., Hase, Y. 2004. Mutation spectrum of tomato induced by seed radiation with carbon and helium ion beams. Acta Horticulture. 637: 257-262.

Meshcherov, E. and Juldasheva, L. 1974. Parthenocarpy in cucumber. Trudy Prikl Bot Genet Selek. 51: 204-13.

Mezzetti, B., Landi, L., Pandolfini, T., Spena, A.2004. The DefH9-iaaM auxinsynthesizing gene increases plant fecundity and fruit production in strawberry and raspberry. $B M C$ Biotechnology. 4:1-10.

Mikhailov, L., Georgiev, K.H. 1987. Line RG a source of parthenocarpy in tomato. Genet SeI. 20:70-71.

Miyatake, K., Saito, T., Negoro, S., Yamaguchi, H., Nunome, T., Ohyama, A., Fukuoka, H. 2012. Development of selective markers linked to a major QTL for parthenocarpy in eggplant (Solanum melongena L.). Theoretical and Applied Genetics. 124:1403-1413.

Molesini, B., Pandolfini, T., Rotino, G.L., Dani, V. and Spena.2009.Aucsia Gene Silencing Causes Parthenocarpic Fruit Development in Tomato[C][W]. Plant Physiology.149:534-48.

More, T.A. and Budgujar, C.D.2002. Isolation of parthenocarpic tropical gynoecious lines in cucumber (Cucumis sativus). Acta Horticulture. 588: 255-260.

Mounet F, Moing A, Kowalczyk M, et al., 2012. Down-regulation of a single auxin efflux transport protein in tomato induces precocious fruit development. Journal of Experimental Botany. 63: 4901-4917.

Nothmann, J. and Koller, D.1975. Effects of growth regulators on fruit and seed development in eggplant (Solanum melongena L.). Journal of Horticultural Science: 50(1):23-27.

Pandolfini, T., Rotino, G.L., Camerini, S., De fez, R., Spena, A. 2002.Optimisation of transgene action at the post-transcriptional level: high quality parthenocarpic fruits in industrial tomatoes. BMCBiotechnology.2: $1-11$.

Pandolfini. T. 2009. Seedless Fruit Production by Hormonal Regulation of Fruit Set. Nutrients. 1: 168-177. 
Paris, H.S.2010. Multiple flowering as an adaptation of summer squash for growing in protected culture. In: Thies JA, Kousik S, Levi A (eds) Cucurbitaceae proceedings. ASHS Press, Alexandria, pp 88-90.

Pecaut, P. and Philouze, J. 1978. A sha pat line obtained by natural mutation. Tomato Genetics Cooperative Reports. 28: 12.

Philouze, J and Maisonneuve, B. 1978. Heredity of the natural ability to set parthenocarpic fruits in the soviet variety Severianin. Tomato Genetics Cooperative Reports. 28: 12-13.

Philouze, J. 1983.Parthenocarpie naturelle chez la tomate. I. Rev. Bibliograph Agro. 3:611-620.

Philouze, J. 1989. Natural parthenocarpy in tomato. IV. A study of the polygenic control of parthenocarpy in line 75159 . Agronomie. 9:63-75.

Pike, L.M and Peterson, C.E.1969.Inheritance of parthenocarpy in the cucumber (Cucumis sativus L.). Euphytica. 18: 1015.

Prohens J, Ruiz J J and Nuez F. 1998. The inheritance of parthenocarpy and associated traits in Pepino. Journal of American Society of Horticultural Science. 1223:376-380.

Prohens, J. Nuez, F. 2008. Handbook of Plant Breeding. Vegetables II: Fabaceae, Liliaceae, Solanaceae and Umbelliferae, Vol. 2. Springer Science; New York; 3040.

Qu, H.Y., Zhang, C. and Sun, Y.2016. The mechanism of seedlessness in watermelon generated using soft-X-ray irradiated pollen. African Journal of Agricultural Research. 11(25): 2200-2204.

Rotino, G.L., Donzella, G., Zottini, M., Sommer, H., Ficcadenti, N., Cirillo, C., Sestili, S., Perri, E., Pandolfini, T. and Spena, A. 1999. Genetic engineering of parthenocarpic vegetable crops. In Genetics and Breeding for Crop Quality and Resistance. (pp. 301-306). Springer, Dordrecht.

Rotino, G.L., Perri, E., Zottini, M., Sommer, H.,
Spena, A. 1997. Genetic engineering of parthenocarpic plants. Nat. Biotechnology. 15:1398-1401.

Rowe, P.R.1974.Parthenogenesis following interspecific hybridization. In: Kasha KJ (ed). Haploids in higher plants. Proc $1^{\text {st }}$ Int Symp, Univ Guelph.

Schijlen, E.G.W.M., de Vos, R.C.H., Martens, S., Jonker, H.H., Rosin, F.M., Molthoff, J.W., Tikunov, Y.M., Angenent, G.C., van Tunen, A.J. Bovy, A.G. RNA.2007.Interference Silencing of Chalcone synthase, the first step in the flavonoid biosynthesis pathway, leads to parthenocarpic tomato fruits. Plant Physiology. 144:1520-1530.

Sharif Hossain, A.B.M. 2015. Seedless Pumpkin vegetable production using gibberellic acid $\left(\mathrm{GA}_{3}\right)$ as plant hormone and genetically modified technique. Global Journal of Biology, Agriculture and Health Sciences.4(3): 6-8.

Singh, H.1978.Parthenocarpy in Trichosanthes dioica Roxb. and Momordica dioica Roxb. Current Science. 47:735.

Soressi, G.P. 1970. Tomato mutants following EMS seed treatments. Tomato Genetics Cooperative Reports. 20: 59.

Stoeva, P.K., Michailov, L. and Georgiev, C.1985.Parthenocarpy in hybrids $L$. esculentllm $\times$ L.pennellii. Rep Tomato Genetics Cooperative. 35:19.

Sugiyama, K., Kami, D., Muro, T. 2014. Induction of parthenocarpic fruit set in watermelon by pollination with bottle gourd (Lagenaria siceraria (Molina) Standl.) pollen. Scientia Horticulture. 171: $1-5$.

Sugiyama, K., Morishita, M. 2000. Production of seedless watermelon using soft-X irradiated pollen. Scientia Horticulture. 84: 255-264.

Sugiyama, K., Morishita, M. 2001. A new method for producing diploid seedless watermelon. ISHS Acta Horticulturae, 588: II International Symposium on Cucurbits.

Sun, Z., Lower, R.L., Staub, J.E. 2006a. Analysis of generation means and 
components of variance for parthenocarpy in cucumber (Cucumis sativus L.). Plant Breeding. 125: 277-80.

Sun, Z., Staub, J., Chung, S., Lower, R. 2006 b. Identification and comparative analysis of quantitative trait loci associated with parthenocarpy in processing cucumber. Plant Breeding. 125:281-7.

Takisawa, R., Maruyama, T., Nakazaki, K., Kataoka, H., Saito, S. Koeda, T. Nunome, H. Fukuoka and A. Kitajima. 2017. Parthenocarpy in the tomato (Solanum lycopersicum L.) cultivar 'MPK-1' is controlled by a novel parthenocarpic gene. The Horticulture Journal. 86 (4): $487-$ 492.

Takisawa, R.,Tetsuya Nakazaki, Tsukasa Nunome, Hiroyuki Fukuoka, Keiko Kataoka, Hiroki Saito Tsuyoshi Habu and Akira Kitajima. 2018. The parthenocarpic gene Pat-k is generated by a natural mutation of SlAGL6 affecting fruit development in tomato (Solanum lycopersicum L.). BMC Plant Biology. 18:72.

Tian ShiBing, Liu FuZhong, Wang YongQing, Luo ZhangYong, Chen YiKang, Liu JunShao, and Lian Yong. 2003. Genetic analysis of parthenocarpy in eggplant. Acta Horticulture Scintia.30 (4): 413-416.

Tiedjens, V.A. 1928. Sex ratios in cucumber flowers as affected by different conditions of soil and light. Journal of Agriculture Research. 36:721-746.

Tiwari, A., Vivian-Smith, A., Voorrips, R. E, Habets, M.E.J., Xue, L. B., Offringa, R and Heuvelink, E. 2011. Parthenocarpic potential in Capsicum annuum L. is enhanced by carpelloid structures and controlled by a single recessive gene. BMC Plant Biology.11:143.

Tomes, D.T. 1997. Seedless hopes bode well for winter vegetables. Nat. Biotechnology.15:1344-1345.

Ueta, R., Abe, C., Watanabe, T., Sugano, S.S., Ishihara, R., Ezura, H. 2017. Rapid breeding of parthenocarpic tomato plants using CRISPR/Cas9. Scientific Reports. 7: 507.
Vardy. E., Lapushner, D., Genizi, A. and Hewitt, J. 1989.Genetics of parthenocarpy in tomato under low temperature regime: I. Line RP 75/59. Euphytica.41:9-15.

Varoquaux, F., Blanvillain, R., Delseny, M. and Gallois. P. 2000. Less is better: new approaches for seedless fruit production. TIBTECH. 18:233-242.

Vijay, O. P. and S. H. Jalikop. 1980. Production of parthenocarpic fruit by growth regulators in kakrol (Momordica cochinchinensis Spreng). India Journal of Horticulture. 37(2): 167-169.

Vivian-Smith, A., Luo, M., Chaudhury, A., Koltunow, A.M. 2001. Fruit development is actively restricted in the absence of fertilization in Arabidopsis. Development. 128: 2321- 2331.

Voraquaux, F.; Blanvillain, R.; Delseny, M.; Gallois, P.2000. Less is better: new approaches for seedless fruit production. Trends Biotechnology. 18: 233-242.

Wang, H.,Jones, B., Li, Z., Frasse, P., Delalande, C., Regad, F., Chaabouni, S., Latché, A., Pech, J.C., Bouzayen, M.2005. The tomato Aux/IAA transcription factor IAA9 is involved in fruit development and leaf morphogenesis. Plant Cell.17: 2676-2692.

Wiebosch, W. A. and Berghoef, J. 1974. Parthenocarpic fruiting in pickling cucumber induced by chlorflurenol. Meded. Fak. Landb. Genetics. 39:625 635.

Wu, Z., Li,L., Zhang, T., Zhang, T.L., Li, J., Lou, Q.F., Chen, J.F. 2015. QTL mapping for parthenocarpy in cucumber. Scientia Agricultura Sinica.48:112-119.

Wu, Z., Zhang, T., Li, L., Xu, J, Qin, X., Zhang, T., Cui, L., Lou, Q., Li, J., Chen, J.2016.Identification of a stable majoreffect QTL (Parth 2.1) controlling parthenocarpy in cucumber and associated candidate gene analysis via whole genome resequencing. BMC Plant Biology. 16:182.

Yan, L.Y., Lou, L.N., Li, X.L., Feng, Z.H, Lou, Q.F. and Chen, J. F. 2010. Inheritance of parthenocarpy in monoecious cucumber. 
Scientia Agricultura Sinica.6:26.

Yan, L.Y., Lou, L.N., Lou, Q.F. and Chen, J.F. 2008. Inheritance of parthenocarpy in gynoecious cucumber. Acta Horticulturae Sinica. 35:1441-1446.

Yin, Z., Malinowski, R., Ziółkowska, A., Sommer, H., Pląder, W., Malepszy, S.2006. The DefH9-iaaM-containing construct efficiently induces parthenocarpy in cucumber. Cell and molecular biology letters. 11: 279-290.

Yoshida, T., Matsunaga, S. and Saito, T. 1998.
Inheritance of parthenocarpic character in eggplant. Journal of Japanese society of Horticulture Science.67:257.

Yoshioka, Y., Shimomura, K. and Sugiyama, M.2018.Exploring an East Asian melon (Cucumis melo L.) collection for parthenocarpic ability. Genetic Resources and Crop Evolution. 65(1): 91-101.

Zijlstra, S. 1985. Parthenocarpy in tomato: two new lines from interspecific crosses. Aadbelangen. 39:92-94.

\section{How to cite this article:}

Gangadhara Rao, P., B.V.G. Prasad, T. Kranthi Kumar, T. Lakshmi Tirupathamma, P. Roshni and Tejaswini, T. 2018. Breeding for Climate Resilient Parthenocarpic Vegetables. Int.J.Curr.Microbiol.App.Sci. 7(11): 2473-2492. doi: https://doi.org/10.20546/ijcmas.2018.711.282 